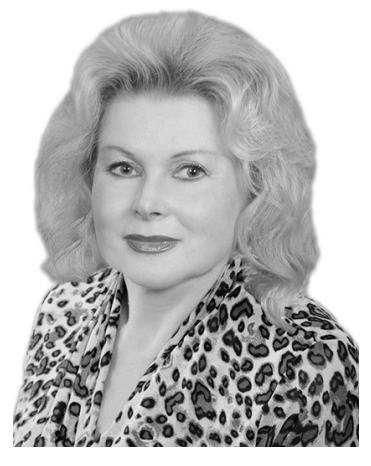

\title{
СУЧАСНІ ПЦДХОДИ ДО ПРОВЕДЕННЯ НАУКОВИХ ДОСЛІДЖЕНЬ У ЮРИСПРУДЕНЦІї
}

\author{
СИБІРНА Рома Іллінічна - д.б.н., професор кафедри \\ теоретичної психології Львівського державного університету \\ внутрішніх справ; професор кафедри кримінального права і \\ процесу Національного університету «Львівська політехніка" \\ УДК 005/168.5:340 \\ ORCID ID: 0000-0002-5704-2004 \\ DOI 10.32782/LAW.UA.2021.3.5
}

Розглянуто сучасні підходи щодо проведення наукових досліджень у галузі юриспрудениї. Проаналізовано особливості використання сучасних методів $i$ методик у різних напрямах наукових розробок юридичної сфери.

Показано, шо на нинішньому етапі розвитку методологія юриспрудениії не лише свідчить про розмежування об'єкта і предмета юриспрудениї, а й забезпечує рух юриспрудениії до нового знання на основі використання концептуальних ідей, методологічних підходів, різноманітного методологічного інструментарію, що має відповідати останнім досягненням науки. Характерною особливістю сучасних науково -юридичних досліджень $\epsilon$ вивчення сочіально-правових аспектів, що здійснюється шляхом аналізу людсъкої діяльності, ї результатів, а також інтересів та потреб людей. Науково - юридичне дослідження повинно мати відповідну програму та певну ефективність.

У ході наукових досліджень у галузі юриспрудениіӥ необхідно комплексно використовувати різні методи, що передбачає визначення їх послідовності та поєднання для створення системи послідовних иілеспрямованих дій, які об’єднуються поняттям «дослідницька діяльність». Такі підходи до проведення наукових досліджень $є$ формою здійснення розвитку юридичної науки.

Вибір методологї сучасного наукового дослідження є основоположним питанням для адекватного та повного визначення об'єкта юриспрудениї.
Сучасним підходам до наукової діяльності у юриспруденцї притаманна плюралістична за своєю природою методологія, оскільки стверджує наявність різних підходів до одного й того ж об'єкта: права і держави. Чим більше підходів пропонує методологія, тим ширші можливості для його багатогранного аналізу юридичною наукою $і$ тим вищою є ефективність наукових досліджень права і держави.

Доведено, що на съогодні науковиям-дослідникам у галузі юриспруденцй важливо мати чітке уявлення про сучасну методологію наукової діяльності, володіти глибокими знаннями ї̈ теорії, технологї, методів та організациї.

Ключові слова: наукове дослідження, методологія, методи, юриспрудениія, аналітична діяльність, системний аналіз, функиіональний підхід.

\section{Постановка проблеми}

Як відомо, юридична наука виникла і розвивається внаслідок наукової діяльності, що спрямована на вивчення права і держави в теоретичному та прикладному аспектах, правових форм організації і функціонування держави та суспільства. Маючи прикладний характер, юридична наука покликана обслуговувати практичні потреби правового регулювання суспільних відносин, сприяти удосконаленню законодавства і правової практики. Тому юридичні наукові знання відрізняються конкретністю, точністю, виражаються в логічно пов’язаних, формалізованих поняттях, категоріях, наукових конструкціях. 
Разом 3 тим, юриспруденція є досить розгалуженою і диференційованою системою наукових знань, видів і форм наукової діяльності. Ї̈̈ зміст складають теорії, наукові закони, постулати та аксіоми, проблеми, гіпотези, методи, поняття та категорії, наукові факти.

3 огляду на складний та динамічний об'єкт пізнання методологія сучасної юриспруденції потребує постійного розвитку. Поява нових і вдосконалення сучасних науково-юридичних методів обумовлена необхідністю точного й адекватного відображення всього розмаїття правової реальності.

Вимога всебічності і точності результатів конкретного юридичного дослідження викликає необхідність комплексного використання ряду методів у їх єдності та взаємному доповненні, методологічній обумовленості, визначення правильного співвідношення між методами «традиційними» для юриспруденції і новими соціологічними, філософськими, політологічними і психологічними підходами до права і держави, емпіричними i теоретичними прийомами їх пізнання, що обумовлюе актуальність дослідження особливості проведення наукових розробок у галузі юриспруденції.

\section{Аналіз останніх досліджень і публікацій}

Останнім часом усе більше наукових досліджень у сфері юриспруденції присвячується питанням методології та організації наукової діяльності .У вітчизняній юридичній науці проблему методології досліджували такі вчені, як Ю. Барабаш, Ю. Бисага, С. Бостан, М. Кельман, В. Ковальчук, М. Козюбра, О. Скакун, О. Скрипнюк, С. Сливка та ін. Рядом науковців здійснено вивчення особливостей проведення наукових досліджень у сфері криміналістики, економічної злочинності, державоправових явищ [1, с. $240 ; 2 ; 3$, с.361; 4, с.504]. Зокрема, видами та функціями наукових досліджень займалися такі науковці, як В. Б. Бєдна, О. В. Кустовська, Ю. П. Аобода, О. Ф. Скакун, Г. С. Цехмістрова та інші. Так, Кельман М. С. розглядає методологію юриспруденції як вчення про структуру, логічну організацію, принципи, методи, засоби і форми діяльності дослід- ника у процесі пізнання ним досліджуваних державно-правових явищ [5, с.34]. Рабінович П. М. вказує на те, що багатоаспектність будь-якого правового феномену зумовлює необхідність застосування системного підходу, у межах якого розрізняють структурно-функціональний, системно-діяльнісний, системно-генетичний та ін.

Проте, в умовах швидкоплинного державно-правового життя залишається актуальним для вивчення ряд питань, які стосуються особливостей проведення науковоюридичних досліджень та розробок.

\section{Постановка завдання}

Метою роботи є аналіз особливостей використання сучасних методів і методик дослідження в науково-юридичній сфері.

\section{Виклад основного матеріалу дослідження}

Оскільки юридична наука є однією з суспільних наук, вона покликана вивчати відносини, які складаються між людьми та їх утвореннями, безпосередньо служити людині. Відповідно, головним завданням юридичної науки є сприяння через державні і правові інститути розквіту особистості і подоланню перешкод на цьому шляху, ефективному використанню людського потенціалу, створенню умов для найповнішої реалізації прав i свобод людини і громадянина.

Наукове юридичне дослідження, маючи свою предметну та методологічну специфіку, у цілому здійснюється за загальними етапами. Воно є головною формою одержання знань про державно-правові явища, що здійснюється за певною процедурою.

На відміну від методів, процедура дослідження - це найбільш загальна система дій i спосіб організації наукового дослідження державно-правових явищ. Вона передбачає наступні етапи:

- формулювання теми дослідження;

- постановку й уточнення мети і завдань;

- висування гіпотез або вихідних положень;

- теоретичну розробку гіпотез, їх формальну перевірку, критику й оцінку, створення програм та інструкцій для емпіричного дослідження; 


\section{Теорія, історія держави і права, конституційне право}

- проведення емпіричних досліджень, збір і опрацювання емпіричних даних;

- порівняння запропонованих гіпотез із даними експерименту та спостережень, остаточну оцінку (у рамках цього дослідження), прийняття або відкидання запропонованих гіпотез;

- формулювання невирішених питань і виявлення труднощів, що ведуть до постановки нових завдань [6].

Оскільки для пізнання правового процесу чи явища необхідно одержати первинну детальну інформацію про нього, здійснити iii ретельний добір і аналіз, то очевидно, що одним із головних інструментів у процесі такого пізнання стає емпірична частина наукового дослідження.

До головних елементів процедури проведення конкретного юридичного дослідження слід віднести:

- спосіб - сукупність головних операцій збору, опрацювання або аналізу даних, властивих певному методу;

- техніку - сукупність спеціальних правил використання того або іншого способу;

- методику - сукупність технічних прийомів і дій, пов'язаних з певним способом, послідовність їх застосування і взаємозв’ язок між ними;

- засоби - матеріальні і нематеріальні інструменти збору, опрацювання, аналізу й узагальнення інформації.

На вибір конкретних елементів і правил процедури впливають компоненти методології більш високих рівнів, зокрема, парадигма, методологічні підходи, методи.

Як відомо, для здійснення наукової діяльності від дослідника вимагається не лише оволодіння певним обсягом необхідних правових знань, а й методологією наукових досліджень, оскільки без використання загальнонаукових і спеціально-наукових методів неможливе жодне дослідження.

У правовій науці розрізняють три види методології:

1. Філософську або фундаментальну методологію - систему світоглядних підходів і методів, які є найзагальнішими і діють на всьому полі наукового пізнання, конкретизуючись і через загальнонаукову, і через спеціально-наукову методологію.
2. Загальнонаукову або міждисциплінарну методологію, яка використовується в переважній більшості наук і базується на загальнонаукових принципах дослідження: історичному, логічному, системному, моделювання тощо.

3. Спеціально-наукову методологію - сукупність специфічних методів кожної конкретної науки, які є базою для вирішення дослідницької проблеми [5, с.42; 7, с.68].

Перш ніж приступити до реалізації наукового дослідження на будь-якому рівні, молоді вчені повинні ознайомитися 3 методологією та методами наукової роботи. При цьому важлива методика вибору проблеми та теми дослідження, збір та систематизація фактів, історія розвитку проблеми, в основі якої лежить задум (ідея) дослідника. Грунтовне дослідження будьякого предмета пізнання, його сутності, ознак, структури, якісних характеристик, динаміки розвитку тощо вимагає від дослідника застосування цілого арсеналу методів. А система підходів, методів і способів наукового дослідження, теоретичні заходи їх використання при вивченні державно-правових явищ становить методологію юридичної науки.

Важливим завданням і обов'язком будьякого дослідника має стати збереження об'єктивності при дослідженні тих чи інших державно-правових явищ і процесів.

Під принципом об'єктивності наукового пізнання розуміється неупереджене ставлення науковця до тих чи інших явищ і процесів, які досліджуються, а також відображення, опис і характеристика їх такими, якими вони є насправді, не приховуючи негативні сторони і не приписуючи їм якостей, яких вони не мають. Керуючись принципом об'єктивності, дослідник має можливість пізнати сутність того чи іншого державно-правового явища, його особливості, передумови виникнення та поширення, форми прояву в сучасній Україні та за кордоном. Принцип об’єктивності тісно пов'язаний 3 принципом всебічності дослідження, сутність якого полягає в тому, щоб здійснити аналіз будьякого явища не окремо, а у зв'язку та взаємодії з іншими, близькими до нього суспільними явищами. 
Багатоаспектність будь-якого правового феномену зумовлює необхідність застосування системного підходу, у межах якого розрізняють структурно-функціональний, системно-діяльнісний, системно-генетичний та інші.

Так, у ході використання структурнофункціонального підходу автор може виокремити структурні компоненти досліджуваного ним явища, а також визначити їх зміст і специфіку. Застосування системнофункціонального методу дає можливість визначити класифікацію форм досліджуваного явища

Використання системно-генетичного підходу в дослідженні дає змогу досліднику розкрити якомога повніше умови зародження та розвитку досліджуваного феномену.

У ході дослідження науковець повинен використовувати ряд методів, традиційних не лише для юриспруденції, а й інших методів, які застосовуються в більшості наук, оскільки цього вимагає всебічність результатів наукового дослідження. Зокрема, юридична наука використовує наступні методи: всезагальні, що характеризують філософську основу пізнання; загальні, які конкретизують всезагальні методи стосовно юридичних наук; спеціальні (окремі), які використовують конкретні юридичні науки [5, с.36].

Так, за допомогою діалектичного методу можна відобразити специфіку не лише досліджуваного явища, а й інших форм його проявів, а також встановити причини виникнення останніх та їх особливості. Порівняльним методом дослідник має змогу визначити тотожні та відмінні риси між подібними за змістом поняттями чи явищами правової дійсності.

Компаративний метод дає змогу порівняти передумови виникнення тих чи інших явищ та їх наслідків з метою пошуку безпосереднього чи опосередкованого зв’язку між ними. Також він дозволяе зрозуміти особливості вітчизняного розвитку тієї чи іншої галузі в контексті світового досвіду, що є важливим кроком на шляху до подальшого прогресу.

Застосування спеціально-юридичного методу дає можливість науковцю проаналі- зувати нормативно-правові акти, які регулюють питання тієї сфери, яку він досліджує.

Систему методів юриспруденції можна поділити на чотири рівні:

- загальнопізнавальні методи, теорія яких розробляється філософськими науками (діалектичною та формальною логікою, науковеденням), частково психологією і математичними науками;

- галузеві методи, теорія яких розробляється галузевими науками (фізикою, хімією, соціологією, психологією і т.п.), що підрозділяються на природньо-наукові методи і методи гуманітарних наук;

- регіональні методи, тобто конкретизовані галузеві методи, у назві яких відбиті окремі явища, процеси (наприклад, спектральний аналіз, анкетування, кореляційний аналіз і т.п.), теорії яких розробляються відповідними науками;

- конкретний метод, що представляє собою галузевий або регіональний метод, конкретизований завданням та об'єктом дослідження (наприклад, люмінесцентний аналіз витравлених штрихів з метою їхнього виявлення) [5, с.46; 8 ].

Крім того, статистичний метод використовується при вивченні та аналізі статистики, наприклад, правоохоронних органів щодо стану та динаміки злочинності в цілому, а також окремо деяких видів злочинів, злочинності неповнолітніх в Україні та за кордоном; встановленні кількості внесених змін та доповнень до нормативно-правових актів тощо.

За допомогою історичного методу в науковця є можливість пізнати досліджуване явище через призму процесу його зародження, розвитку та набуття ним тих властивостей, які характеризують його сутність на сучасному етапі розвитку суспільства. Цей метод дає змогу дослідити, яким чином історичне минуле України вплинуло на формування, розвиток тих чи інших явищ сьогодення.

Історико-правові дослідження слід проводити, спираючись на сукупність знань таких наук, як історія держави і права України, історія політичних і правових учень, а також теорія держави і права, конституційне право зарубіжних країн, філософія та ін. 


\section{Теорія, історія держави і права, конституційне право}

Важливе значення у ході логічного осмислення сутності різноманітних явищ має метод абстрагування, аксіологічний метод, соціологічний метод, який полягає в дослідженні явищ не на рівні абстрактних категорій, а за допомогою конкретних соціальних фактів -метод анкетування, опитування та ін.

На сьогодні у галузі юриспруденції широко користуються характерними для неї особливими методами пізнання. Це методи юридичних наукових дисциплін, застосовувані в конкретній галузі наукового знання або в кількох науках, тобто сфера їх застосування обмежена.

Спеціальні методи окремих юридичних наук поділяють на їхні власні методи, що розроблені й застосовуються тільки ними або в деяких юридичних наукових дисциплінах (так, у криміналістиці - це технікокриміналістичні й структурно-криміналістичні групи методів), і спеціальні методи інших наук, розроблені в юридичних і неюридичних наукових дисциплінах ( у криміналістиці - фізичні, хімічні, антропологічні тощо, у юридичній психології - психологічні методи вивчення особистості, методи впливу на неї, методи перевірки психічних якостей особистості та ін.). [1, с.238; 2; 9, с.140].

До найбільш поширених спеціально-наукових методів, які застосовуються при дослідженні правової реальності, слід віднести:

- метод конкретно-соціологічних досліджень - аналітично-синтетична переробка й відбір необхідної інформації про той аспект правової реальності, що досліджується;

- метод контентаналізу - кількісний аналіз текстів і текстових масивів 3 метою подальшої змістовної інтерпретації виявлених закономірностей;

- статистично-математичні методи - дають можливість отримання й обробки кількісних показників державно-правових явищ і процесів;

- метод соціально-правового експерименту - вивчення соціально-правових явищ і процесів, що здійснюються шляхом спостереження за зміною досліджуваного об'єкта під впливом факторів, що контролюють i скеровують їх розвиток;

- кібернетичний метод - це сукупність прийомів, що дозволяють за допомогою сис- теми понять, законів і технічних засобів кібернетики пізнати правові явища;

- порівняльно-правовий метод - зіставлення різних державних і правових систем, інститутів, категорій з метою виявлення рис подібності або відмінності між ними;

- формально-юридичний метод є традиційним для юридичної науки і становить необхідний ступінь у пізнанні права, оскільки дозволяє вивчати внутрішню будову держави і права, їх найважливіші властивості, класифікувати головні ознаки, визначати юридичні поняття й категорії, встановлювати прийоми тлумачення правових норм і актів, систематизувати державно-правові явища;

- логіко-юридичний метод - включає засоби і способи логічного вивчення і пояснення права і є заснованим на формах мислення і законах формальної логіки;

- метод альтернатив - вирішення наукових проблем шляхом зіставлення і критики протилежних одна одній теорій (концепцій, гіпотез).

Разом 3 тим, для максимально повного i всебічного дослідження правової реальності необхідно комплексно використовувати ширший спектр наукової методології на базі єдності і взаємодоповнюваності методів наукового пізнання, визначення правильного співвідношення між традиційними для юриспруденції методами і новими позаюридичними підходами до усвідомлення правової реальності. Сучасна методологія права постійно розвивається. Необхідність такого розвитку обумовлена як ускладненням і динамізмом об'єкта пізнання правових феноменів, так і самого процесу пізнання і його засобів [10, с.56].

Слід зазначити, що юридична наука сьогодні не може обмежуватися власними (спеціальними) методами, а повинна виходити за їх межі. Про це свідчить і розроблена на сьогодні вченими видова диференціація методів дослідження [ $11 ; 12$, с.9 ].

Визначаючи роль методологічного підходу в конкретному дослідженні, коректніше вести мову не про обумовленість ними напряму процесу встановлення істини, а погляду на предмет дослідження. Вказаний умовивід грунтується на аксіоматичних ідеях про напрям дослідження і шлях пізнання [10, c.58]. 
Окрім того, при проведенні наукових досліджень необхідно спиратись на сучасну технологію мислення при проведенні наукового пошуку. Найбільш вдалими підходами щодо дослідження соціальних процесів і систем $є$ організаційний підхід або теорія організації, у яку органічно вписуються некласичні та постнекласичні парадигми розвитку науки, у тому числі в галузі правознавства. При цьому головне завдання науковцядослідника полягає у тому, щоб додавати у правовій науці до традиційного класичного підходу сучасні некласичний та постнекласичний. Такий шлях передбачає вирішення багатьох складних завдань.

\section{Висновки і перспективи подальшого} дослідження у цьому напрямі

Сучасні підходи до проведення наукових досліджень є формою здійснення розвитку юридичної науки.

Вибір методології сучасного наукового дослідження $\mathrm{\epsilon}$ основоположним питанням для адекватного та повного визначення об'єкта юриспруденції.

На нинішньому етапі розвитку методологія юриспруденції не лише свідчить про розмежування об'єкта і предмета юриспруденції, а й забезпечує рух юриспруденції до нового знання на основі використання концептуальних ідей, методологічних підходів, різноманітного методологічного інструментарію, що має відповідати останнім досягненням науки.

У ході наукових досліджень у галузі юриспруденції необхідно комплексно використовуються різні методи, що передбачає визначення їх послідовності та поєднання для створення системи послідовних цілеспрямованих дій, які об'єднуються поняттям «дослідницька діяльність».

Сучасним підходам до наукової діяльності у юриспруденції притаманна плюралістична за своєю природою методологія, оскільки стверджує наявність різних підходів до одного й того ж об'єкта: права і держави. Чим більше підходів пропонує методологія, тим ширші можливості для його багатогранного аналізу юридичною наукою і тим вищою є ефективність наукових досліджень права i держави.
На сьогодні науковцям-дослідникам у галузі юриспруденції важливо мати уявлення про сучасну методологію наукової діяльності, володіти глибокими знаннями іiі теорії, технології, методів та організації.

\section{1. Щур Б.В. Функції окремих} криміналістичних методик. Науковий вісник Чернівецького університету. Серія «Правознавство». 2011. Вип. 578. С. 231-242.

2. Хомів О. В. Особливості проведення науково-економічних досліджень. Ефективна економіка. 2015. № 5. Електронне фахове видання. URL : http://www.economy.nayka.com. ua/?op = 1\&z=4048 (дата звернення: 25.09.2021).

3. Журавель В.А. Окремі методики в системі криміналістичних знань. Науковий вісник Аьвівської комериійної академї. Серія «Юридична». 2015. Вип. 1. С. 358-366.

4. Сибірна Р.І.,Сибірний А.В., Хомів О.В. Місце судової експертизи у господарському процесі. Науковий вісник Нy «Аьвівсъка політехніка». Серія юридичні науки. 2017. №865. С. 502-506.

5. Кельман М. С. Методологія сучасного правознавства: становлення та основні напрямки розвитку. Психологія і суспільство. 2015. № 4. С. 33-46. Данильян О. Г., Дзьобань О.П. Організація та методологія наукових досліджень : навч. посіб. Харків : Право, 2017. 448 с.

6. Кунєв Ю. Методологія дослідження державно-правових явищ як актуальна проблема. Право Украӥни. 2009. № 11. С.118.

7. . Гуторов O.I. Методологія та організація наукових досліджень: навч. посіб. Харків: ХНАУ, 2017. 272 с.

8. Жаровська I. М. Щодо проблем методології теорії держави і права. Вісник Нацуіонального університету «Һьвівсъка політехніка». Юридичні науки. 2015. № 827. С.138-141.

9. Сердюк I. А. Інтерпретація поняття «методологічний підхід» у сучасній правничій науці. Науковий вісник Дніпропетровського державного університету внутрішніх справ. 2018. № 4. С.52-58.

10. Авакьян М.В. Теоретические основы модульной методики расследования и поддержания государственного обвинения. Союз криминалистов и криминологов. 2019.№ 2.364 c. 


\section{References:}

1. Shchur B.V. Funktsiyi okremykh kryminalistychnykh metodyk. Naukovyy visnyk Chernivets'koho universytetu. Seriya «Pravoznavstvo». 2011. Vyp. 578. S. 231-242.

2. Khomiv O. V. Osoblyvosti provedennya naukovo-ekonomichnykh doslidzhen'. Efektyvna ekonomika. 2015. № 5. Elektronne fakhove vydannya. URL : http://www. economy.nayka.com.ua/?op $=1 \& z=4048$ (data zvernennya: 25.09.2021).

3. Zhuravel' V.A. Okremi metodyky v systemi kryminalistychnykh znan'. Naukovyy visnyk L'vivs'koyi komertsiynoyi akademiyi. Seriya «Yurydychna». 2015. Vyp. 1. S. 358-366.

4. Sybirna R.I.,Sybirnyy A.V., Khomiv O.V. Mistse sudovoyi ekspertyzy u hospodars'komu protsesi. Naukovyy visnyk NU «L'vivs'ka politekhnika». Seriya yurydychni nauky. 2017. №865. S. 502-506.

5. Kel'man M. S. Metodolohiya suchasnoho pravoznavstva: stanovlennya ta osnovni napryamky rozvytku. Psykholohiya i suspil'stvo. 2015. № 4. S. 33-46. Danyl'yan O. H., Dz'oban' O.P. Orhanizatsiya ta metodolohiya naukovykh doslidzhen' : navch. posib. Kharkiv : Pravo, 2017. $448 \mathrm{~s}$.

6. Kunyev YU. Metodolohiya doslidzhennya derzhavno-pravovykh yavyshch yak aktual'na problema. Pravo Ukrayiny. 2009. № 11. S.118.

7. . Hutorov O.I. Metodolohiya ta orhanizatsiya naukovykh doslidzhen': navch. posib. Kharkiv: KHNAU, 2017. 272 s.

8. Zharovs'ka I. M. Shchodo problem metodolohiyi teoriyi derzhavy i prava. Visnyk Natsional'noho universytetu «L'vivs'ka politekhnika». Yurydychni nauky. 2015. № 827. S.138-141.

9. Serdyuk I. A. Interpretatsiya ponyattya «metodolohichnyy pidkhid» u suchasniy pravnychiy nautsi. Naukovyy visnyk Dnipropetrovs'koho derzhavnoho universytetu vnutrishnikh sprav. 2018. № 4. S.52-58.

10. Avak'yan M.V. Teoretycheskye osnovy modul'noy metodyky rassledovanyya y podderzhanyya hosudarstvennoho obvynenyya. Soyuz krymynalystov y krymynolohov. 2019.№ $2.364 \mathrm{~s}$. doctor of Biological Sciences, Professor, Professor at the Department of theoretical psychology of Lviv State University of Internal Affairs; Professor of the Department of Criminal Law and Procedure Educational and Scientific Institute of Law, Psychology and Innovative Education, Lviv Polytechnic National University

ORCID ID: 0000-0002-5704-2004 MODERN APPROACHES TO SCIENTIFIC RESEARCH IN JURISDICTION

Modern approaches to conducting research in the field of jurisprudence are considered. The peculiarities of the use of modern methods and techniques in various areas of scientific research in the legal field are analyzed.

It is shown that at the current stage of development the methodology of jurisprudence not only shows the distinction between object and subject of jurisprudence, but also provides the movement of jurisprudence to new knowledge based on the use of conceptual ideas, methodological approaches, various methodological tools. A characteristic feature of modern scientific and legal research is the study of socio-legal aspects, which is carried out by analyzing human activity, its results, as well as the interests and needs of people. Scientific and legal research should have an appropriate program and some effectiveness.

In the course of research in the field of jurisprudence, it is necessary to use a variety of methods, which involves determining their sequence and combination to create a system of consistent targeted actions, which are united by the concept of «research». Such approaches to research are a form of development of legal science. The choice of methodology of modern scientific research is a fundamental issue for adequate and complete definition of the object of jurisprudence.

Modern approaches to scientific activity in jurisprudence are characterized by a pluralistic in nature methodology, as it states the existence of different approaches to the same object: law and the state. The more approaches the methodology offers, the greater the opportunities for its multifaceted analysis by legal science and the higher the efficiency of scientific research of law and the state.

It is proved that today it is important for researchers in the field of jurisprudence to have a clear idea of the modern methodology of scientific activity, to have deep knowledge of its theory, technology, methods and organization.

Keywords: scientific research, methodology, methods, jurisprudence, analytical activity, system analysis, functional approach. 